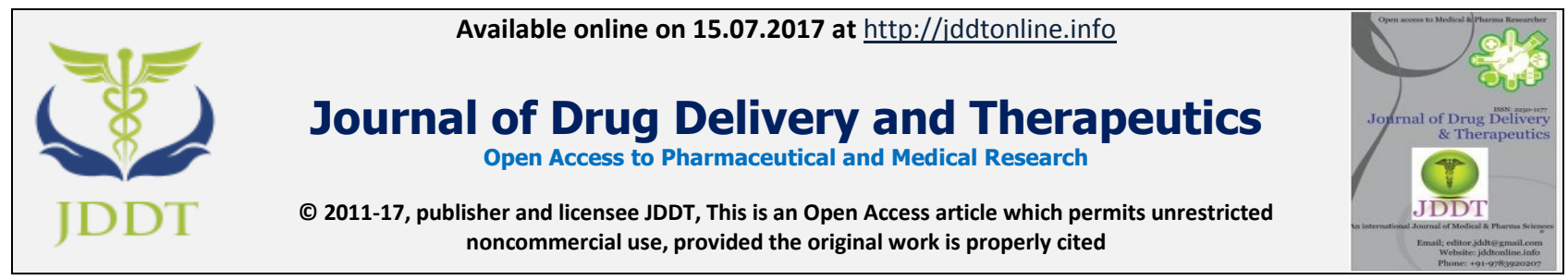

Open $\odot$ Access

Research Article

\title{
FORMULATION AND EVALUATION OF FLOATING DRUG DELIVERY OF CEFOTAXIME USING RAFT FORMING APPROACH
}

\author{
Yerikala Ramesh ${ }^{1}$, Pudi Venkata Prasad*1 ${ }^{1}$ K. Saravanakumar ${ }^{2}$, Vadhireddy Sireesha ${ }^{1}$ \\ ${ }^{1}$ Department of Pharmaceutics, Ratnam Institute of Pharmacy, Pidathapolur (V \& P), Muthukur (M), SPSR Nellore (Distt) - 524346, Andhra \\ Pradesh, India \\ ${ }^{2}$ Department of Pharmaceutics, Sree Vidyanikethan College of Pharmacy, A Rangampeta,Chandragiri Mandal,Tirupati, Chittoor Dist- \\ 517102, Andhra Pradesh, India
}

\section{ABSTRACT}

The cefotaxime is a broad spectrum cephalosporin antibiotic. It is mainly used in the treatment of bacterial infections. Cefotaxime is a suitable candidate for controlled release administration due to its short elimination time 1 hour. The main aim of the present investigation is to increase the gastric residence time by preparing floating drug delivery by using raft forming approach thereby improving bioavailability. The prepared Cefotaxime floating drug delivery by using raft forming approach were evaluated for hardness, weight variation, thickness, friability, drug content uniformity, total floating time, In-vitro dissolution studies and buoyancy lag time. Floating tablets were formulated using direct compression technique. Various polymers are used in the formulation they Micro crystalline cellulose used as binder, HPMC K15M, Guargum used as hydrophilic polymers, Chitosan, Sodium bicarbonate was incorporated as an effervescent substance, Sodium alginate used as viscous gel forming agent, Magnesium streate used as lubrication, talc was used as diluent. The formulated Cefotaxime tablet to be evaluated the following parameters as follow Weight variation (mg), Hardness, Thickness, Friability, Drug content uniformity, Floating lag time, the in vitro cumulative amount of drug released was shown the F7 is $99.28 \%$ within 45 minutes the comparative studies with marketed formulations F7 show the better results.

Keywords: Cefotaxime, Direct compression, Raft forming, floating drug delivery system.

Article Info: Received 28 May, 2017; Review Completed 13 July, 2017; Accepted 14 July, 2017; Available online 15 July, 2017

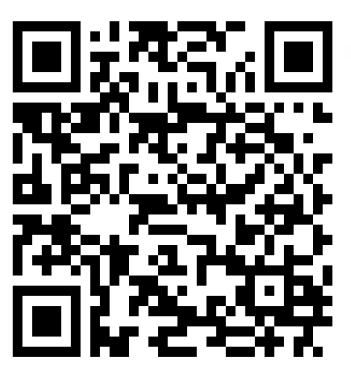

Cite this article as:

Yerikala Ramesh, Pudi Venkata Prasad, Saravanakumar K, Vadhireddy Sireesha, Formulation and evaluation of floating drug delivery of cefotaxime using raft forming approach, Journal of Drug Delivery and Therapeutics. 2017; 7(4):110-119

DOI: http://dx.doi.org/10.22270/jddt.v7i4.1473

*Address for Correspondence

Yerikala Ramesh, Department of Pharmaceutics, Ratnam Institute of Pharmacy, Pidathapolur (V \& P), Muthukur (M), SPSR Nellore (Distt) - 524346, Andhra Pradesh, India.

Email: venkat.pharmacy2k15@gmail.com, Mobile No: +918247743452

\section{INTRODUCTION}

The Oral administration is the most convenient and preferred means of any drug delivery to the systematic circulation ${ }^{1}$. Oral controlled release drug delivery have recently been of increasing interest in pharmaceutical field to achieve improved therapeutic advantages, such as ease of dosing administration, patient compliance and flexibility in formulation. This route has high patient acceptability, primarily due to ease of administration. Over the years, oral dosage forms have become increasingly sophisticated with major role being played by control release drug delivery system ${ }^{2}$. The Control release drug delivery system release drug at a predetermined rate, as determined by drug's pharmacokinetics and desired therapeutic concentration. Raft forming system has received much attention for the delivery of antacids and drug delivery for gastrointestinal infections and disorders. The basic mechanism involved in the raft formation includes the formation of viscous cohesive gel in contact with gastric fluids, wherein each portion of the liquid swells forming 
a continuous layer called raft. The raft floats because of the buoyancy created by the formation of $\mathrm{CO}_{2}$ and act as barrier to prevent the reflux of gastric content like $\mathrm{HCl}$ and enzymes into the esophagus. Usually, the system contains a gel forming agent and alkaline bicarbonates or carbonates responsible for the formation of to make the system less dense and float on the gastric fluids ${ }^{3}$. The floating drug delivery system by raft forming method enhances the absorption of drug in stomach and also to increase the bioavailability of drug. Gastric retentive time is increased because of buoyancy studies to avoidance of gastric irritation ${ }^{4}$. These delivery system also used to reduce the development of drug resistant bacteria and maintain the effectiveness of cefotaxime and other antibacterial drugs. It should be used only to treat or prevent infections that are proven or strongly suspected to be caused by bacteria. Cefotaxime sodium is a bactericidal agent that acts by inhibition of bacterial cell wall synthesis ${ }^{5}$. Cefotaxime has activity in the presence of some beta lactamases, both penicillinases and cephalosporinases, of Gram negative and Gram positive bacteria. Cefotaxime is a $\beta$-lactam antibiotic as a class, $\beta$-lactams inhibit bacterial cell wall synthesis by binding to one or more of the penicillin-binding proteins.

\section{MATERIALS AND METHODS:}

Cefotaxime was procured as a gift sample from Hetero Drug Limited, Hyderabad, India. Microcrystalline cellulose, Sodium alginate \& HPMCK15M was obtained from Pharmaceutical Pvt Ltd, Mumbai. Guar gum \& chistosan was obtained from India sea foods cochin, Sodium bicarbonate, talc \& Magnesium stearate was obtained form S.D. Fine Chemical Ltd, Mumbai. All other reagents used were of analytical grade.

\section{Methodology}

\section{Compatability Studies}

FTIR Studies: The compatibility between pure drug and polymer like Cefotaxime, HPMC K15M, guar gum, chitosan and mixture of compounds were prepared in the form of $\mathrm{KBr}$ Pellets and subjected for scanning from $4000 \mathrm{~cm}^{-1}$ to $400 \mathrm{~cm}^{-1}$ using FTIR spectroscopy ${ }^{6}$.

\section{Formulation of Floating Tablet of Cefotaxime}

The Floating Raft forming approach tablets of cefotaxime were prepared through direct compression method. The preparations of Cefotaxime by various steps involved in tablet production are sieving, mixing, lubrication and compression ${ }^{7}$. Microcrystalline cellulose use as binder, HPMC $\mathrm{K} 15 \mathrm{M}$ used as synthetic hydrophilic polymer. Guar gum and chitosan used as natural hydrophilic polymer. Sodium alginate use as viscous gel forming, sodium bicarbonate used as gas generating agent. Talc is used as diluents, magnesium stearate used as lubricant. Finally, the powder mixture was compressed into tablets using rotator tablet punching machine at the weight of $500 \mathrm{mg}$ each. The below expressed gastro retentive drug delivery of cefotaxime tablets performed a different formulation from F1 to F9 batches study with various concentrations of different polymers.

Table 1: Formulation of gastro retentive of cefotaxime tablet prepared by using different polymers

\begin{tabular}{|l|l|l|l|l|l|l|l|l|l|}
\hline \multirow{2}{*}{ Ingrdients } & \multicolumn{9}{|c|}{ Formulation code } \\
\cline { 2 - 10 } & F1 & F2 & F3 & F4 & F5 & F6 & F7 & F8 & F9 \\
\hline Cefotaxime (mg) & 150 & 150 & 150 & 150 & 150 & 150 & 150 & 150 & 150 \\
\hline Micro crystalline cellulose (mg) & 165 & 115 & 85 & 165 & 115 & 85 & 165 & 115 & 85 \\
\hline Sodium alginate (mg) & 70 & 70 & 90 & 70 & 70 & 90 & 70 & 70 & 90 \\
\hline HPMC K15M (mg) & 60 & 110 & 110 & --- & --- & --- & --- & --- & --- \\
\hline Guar gum (mg) & --- & --- & --- & 60 & 110 & 110 & --- & --- & --- \\
\hline Chitosan (mg) & --- & --- & ---- & --- & --- & --- & 60 & 110 & 110 \\
\hline Sodium Bicarbonate (mg) & 40 & 40 & 50 & 40 & 40 & 50 & 40 & 40 & 50 \\
\hline Talc (mg) & 9 & 9 & 9 & 9 & 9 & 9 & 9 & 9 & 9 \\
\hline Magnesium stearate (mg) & 6 & 6 & 6 & 6 & 6 & 6 & 6 & 6 & 6 \\
\hline Total (mg) & 500 & 500 & 500 & 500 & 500 & 500 & 500 & 500 & 500 \\
\hline
\end{tabular}

\section{Pre Compression Parameters}

Angle of repose: Angle of repose is defined as the maximum angle between the surface of pile of the powder and the horizontal plane ${ }^{10}$. Fixed funnel method was used. A funnel was fixed with its tip at a given height (h), above a flat horizontal surface on which a graph paper was placed. Powder was carefully poured through the funnel until the apex of the conical pile formed just reached the tip of the funnel ${ }^{8}$. These studies were carried out before and after incorporating lubricant/glidant. The angle of repose $(\Theta)$ was then calculated.

$$
\Theta=\tan ^{-1}(\mathbf{h} / \mathbf{r})
$$

Where $\Theta=$ Angle of repose,

$\mathrm{h}=$ Height of pile,

$r=$ Radius of the base of pile.

Bulk density: Bulk density was determined by using bulk density apparatus, during measurement accurately weighed quantity of the powder were taken in a measuring cylinder and recording the volume and weight of the total powder ${ }^{9}$. Bulk density is expressed in $\mathrm{gm} / \mathrm{ml}$ and is given by,

$\mathrm{BD}=\mathrm{W} / \mathbf{V}_{\mathrm{o}}$

Where, $\mathrm{BD}=$ Bulk density $(\mathrm{gm} / \mathrm{ml})$

$\mathrm{W}=$ weight of powder $(\mathrm{gm})$

$\mathrm{V}_{\mathrm{o}}$ Initial volume of the powder $(\mathrm{ml})$ 
Tapped density: Tapped density was determined by using Tapped density apparatus during measurement accurately weighed quantity of the powder were taken in a measuring cylinder and recording the volume of powder after 30 tapping and weight of the total powder 10 .

$$
\begin{gathered}
\mathbf{T D}=\mathbf{W} / \mathbf{V}_{\mathbf{F}} \\
\text { Where, TD }=\text { Tapped density }(\mathrm{gm} / \mathrm{ml}) \\
\mathrm{W}=\text { weight of powder }(\mathrm{gm}) \\
\mathrm{V}_{\mathbf{F}}=\text { Final volume of powder }(\mathrm{ml})
\end{gathered}
$$

Compressibility index (or) Carr's index: Compressibility index is an important measure that can be obtained from the bulk and tap densities ${ }^{11}$. A material having values less than 20 to $30 \%$ is defined as the free flowing material, based on the apparent bulk density and tapped density, the percentage compressibility of the bulk drug was determined by using the following formula.

\section{Compressibility index $=\frac{T D-B D}{T D} \times 100$}

Where, $\mathrm{TD}=$ Tapped density of the powder,

$\mathrm{BD}=$ Bulk density of the powder.

Hausner's ratio: It indicates the flow properties of the powder. The ratio of tapped density to bulk density of the powder is called Hausner's ratio.

\section{Hausner's Ratio $=$ TD/BD}

Where, $\mathrm{TD}=$ Tapped density of the powder,

$\mathrm{BD}=$ Bulk density of the powder.

\section{Post Compression Parameters}

Hardness: The hardness of ten tablets was measured using Monsanto tester. Resistance of the tablet during transportation or breakage under storage conditions and handling before usage depends on its hardness ${ }^{12}$. The hardness was measured in terms of $\mathrm{kg} / \mathrm{cm}^{2}$. Five tablets were chosen randomly and tested for hardness. The average hardness of five tablets was recorded.

Thickness: Thickness was measured using a calibrated vernier calliper. It was determined for check the thickness of tablet ${ }^{13}$. Five tablets of each formulation were picked randomly and thickness was measured individually.

Friability: The friability of the prepared tablets was determined using Roche friability apparatus. It is expressed in percentage $(\%)$. To calculate the percentage friability determines 10 tablets initial weight and transferred into friabilator. The friabilator was operated at $25 \mathrm{rpm}$ for four minutes ${ }^{14}$. After four minutes the tablets were weighed again. Then $\%$ friability was then calculated using formula.

$$
\% \text { Friability }=\frac{\text { Initial } \boldsymbol{W} \text { t-Final } \boldsymbol{W t}}{\text { Initial } \boldsymbol{W t}} \times 100
$$

Weight variation: The weight of the tablet being made was determined to ensure that a tablet contains the proper amount of drug. Twenty tablets were selected at random from each formulation and weighed on electronic weighing balance. The average weight of the tablets was determined ${ }^{15}$. The weight of individual tablets was compared with the average weight variation.

Drug content uniformity: The drug content of prepared tablets was accurately weight and finely powered by pestle in a mortar. Weighed tablet of each powder equivalent to $400 \mathrm{mg}$ of cefotaxime was transferred in to volumetric flask, dissolved in $60 \mathrm{ml}$ of $0.1 \mathrm{~N} \mathrm{HCL}$ and content of the flask were sonicated for 15 minutes. Then the volume was made up to $100 \mathrm{ml}^{16}$. The samples were analyzed UV-Visible spectrophotometer, and concentration of the drug in the sample was calculated.

In-Vitro Buoyancy Studies: The in vitro buoyancy was determined by floating lag time. The time between introduce of dosage form and its buoyancy on the simulated gastric fluid and the time during which the dosage form remain buoyant were measured. The time taken for dosage form to emerge on surface of medium called floating lag time. Method described by the tablets was placed in a $100 \mathrm{ml}$ beaker containing $0.1 \mathrm{~N}$ HCL. The time required for the tablet to rise to the surface and float was determined as floating lag time ${ }^{17}$.

In-vitro dissolution studies: Dissolution of the tablets was carried out on USP XXXIII dissolution type II apparatus using paddle. The tablet was fixed to the paddle by hydration mechanism $900 \mathrm{ml}$ of $0.1 \mathrm{~N} \mathrm{HCL}$ as dissolution medium was filled in a dissolution vessel and the temperature of the medium was set at $37 \pm 0.5^{\circ} \mathrm{c}$. The rotational speed of the paddle was set at $100 \mathrm{rpm}{ }^{18}$. At particular intervals $5 \mathrm{ml}$ of sample was withdrawn at predetermined time intervals of 5 mints, 10 mints, 15 mints, 20 mints, 25 mints, 30 mints, 35 mints, 40 mints, 45 mints and same volume of fresh medium was replaced. The withdrawn samples were diluted to $10 \mathrm{ml}$ with $0.1 \mathrm{~N}$ HCL, filtered and analyzed on UV spectrophotometer at $752 \mathrm{~nm} \mathrm{0.1NHCL} \mathrm{using} \mathrm{buffer} \mathrm{as} \mathrm{a}$ blank. Percentage cumulative drug release was calculated.

Raft strength measurement by in house method: A tablet powder equivalent to unit dose was transferred to $150 \mathrm{ml}$ of $0.1 \mathrm{~N} \mathrm{HCL}$ and maintained at $37^{\circ} \mathrm{c}$ in a $250 \mathrm{ml}$ glass beaker. Each raft was allowed to form around an L- shaped wire probe (diameter: $1.2 \mathrm{~mm}$ ) held upright in the beaker throughout the whole period $(30 \mathrm{~min})$ of raft development. Raft strength was estimated using the modified balance method ${ }^{19}$. Water was added drop wise to the pan and the weight of water required to break the raft was recorded.

Data analysis: To analyze the mechanism of release and release rate Zero order, first order, Higuchi matrix and Peppa's model. Based on the r-value, the best-fit model was selected

Zero order kinetics: Drug dissolution from pharmaceutical dosage forms that do not disaggregate and release the drug slowly, assuming that the area does not change and no equilibrium conditions are obtained can be represented by the following equation ${ }^{20}$.

$$
Q \mathbf{t}=\mathbf{Q}_{\mathbf{o}}+\mathbf{K}_{\mathbf{o}} \mathbf{t}
$$

Where $\mathrm{Qt}=$ amount of drug dissolved in time $\mathrm{t}$,

$\mathrm{Q}_{\mathrm{o}}=$ initial amount of the drug in the solution,

$\mathrm{K}_{\mathrm{o}}=$ zero order release constant. 
First order kinetics: To study the first order release rate kinetics, the release rate data were fitted to the following equation $^{21}$.

$$
\log Q t=\log Q_{0} K_{1} t / 2.303
$$

Where Qt is the amount of drug released in time $t, Q_{o}$ is the initial amount of drug in the solution and $K_{1}$ is the first order release constant.

Higuchi's model: Higuchi's developed several theoretical models to study the release of water soluble and low soluble drugs incorporated in semisolids and/or solid matrices ${ }^{22}$. Mathematical expressions were obtained for drug particles dispersed in a uniform matrix having as diffusion media. And the equation is,

$$
\mathrm{Mt} / \mathrm{M} \infty=\mathrm{KH} \mathrm{t1} / 2
$$

Where,

Mt and $M \infty$ are cumulative amount of drug release at time $\mathrm{t}$ and infinite time,

$\mathrm{KH}=$ Higuchi dissolution constant reflection formulation characteristics.
If the Higuchi model of drug release is obeyed, then a plot of $\mathrm{Mt} / \mathrm{M} \infty$ versus $\mathrm{t} 1 / 2$ will be straight line with slope of KH.

Korsmeyer- Peppas Model: The power law describes the fractional drug release is exponentially related to the release time and adequately describes the release of drug from slabs, cylinders and spheres, as expressed in following equatiion ${ }^{23}$.

$$
\begin{aligned}
& \text { Mt } / M \infty=K t n \\
& \log (M t / M \infty)=\log K+n \log t
\end{aligned}
$$

Stability Studies: Accelerated stability study of gastro retentive drug delivery of cefotaxime $(100 \mathrm{mg})$ brand name was claforan by using raft forming approach. Stability study of tablets containing Cefotaxime was performed at following temperatures for one month and three months ${ }^{24}$.

Long term testing: 25oC/ 60\% RH (1Month) (3Month)

Accelerated testing: $40 \mathrm{oC} / 75 \% \mathrm{RH}$ (1Month) (3Month)

\section{RESULTS AND DISCUSSION}

Preformulation studies:

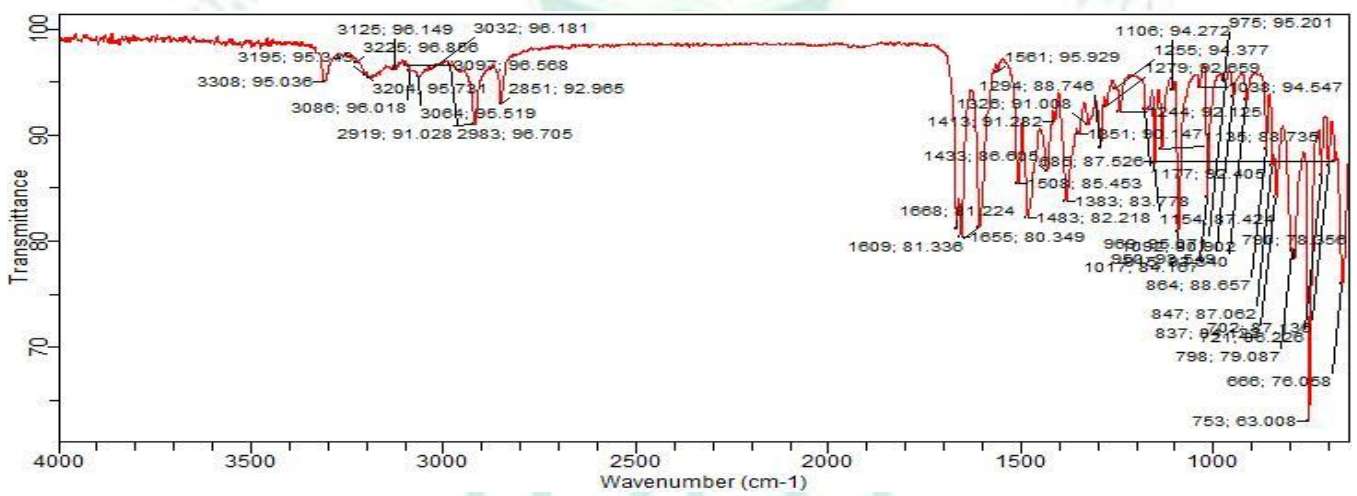

Figure 1: FTIR Spectrum of Cefotaxime

Drug and interaction (FTIR) study: From the spectra of Cefotaxime, excipients physical mixture of drug was observed that all characteristic peaks of Cefotaxime were present in the combination spectrum, thus indicating compatibility of the Cefotaxime and excipients. IR spectra of individual polymers and combination of Cefotaxime with all individual polymers. As shown in table $2 \&$ figure 1-6.

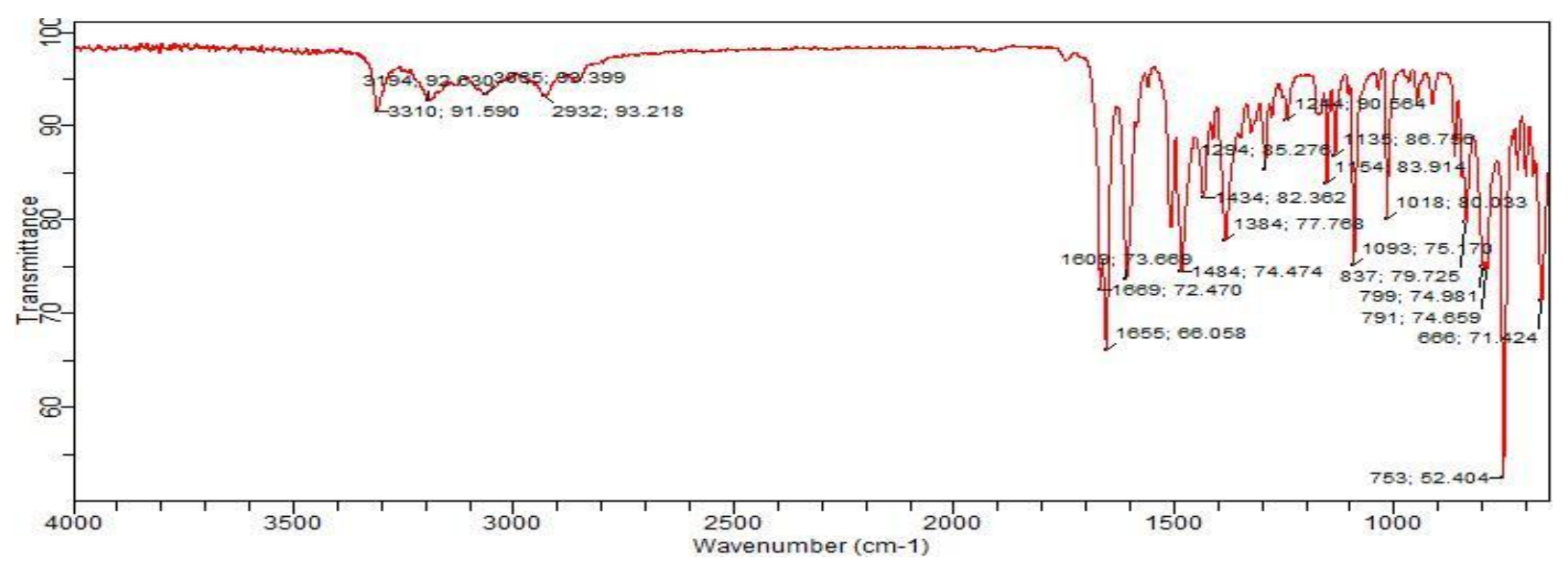

Figure 2: FTIR Spectrum of HPMC K15M 


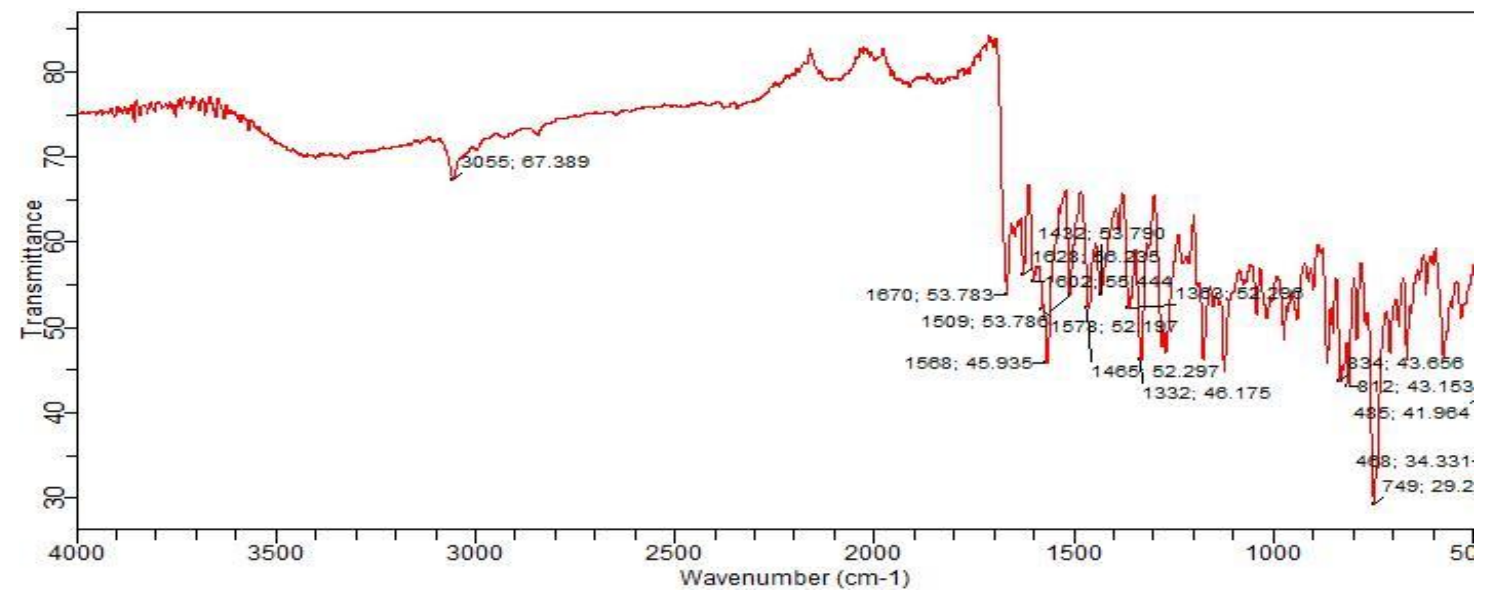

Figure 3: FTIR Spectrum of Guargum

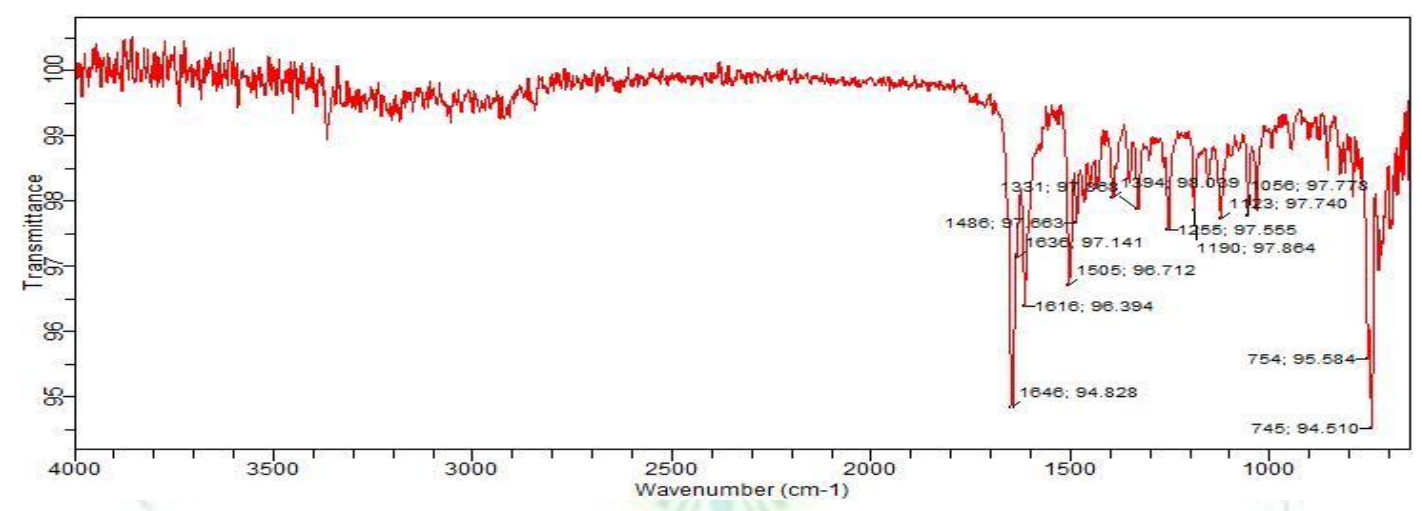

Figure 4: FTIR Spectrum of Chitosan

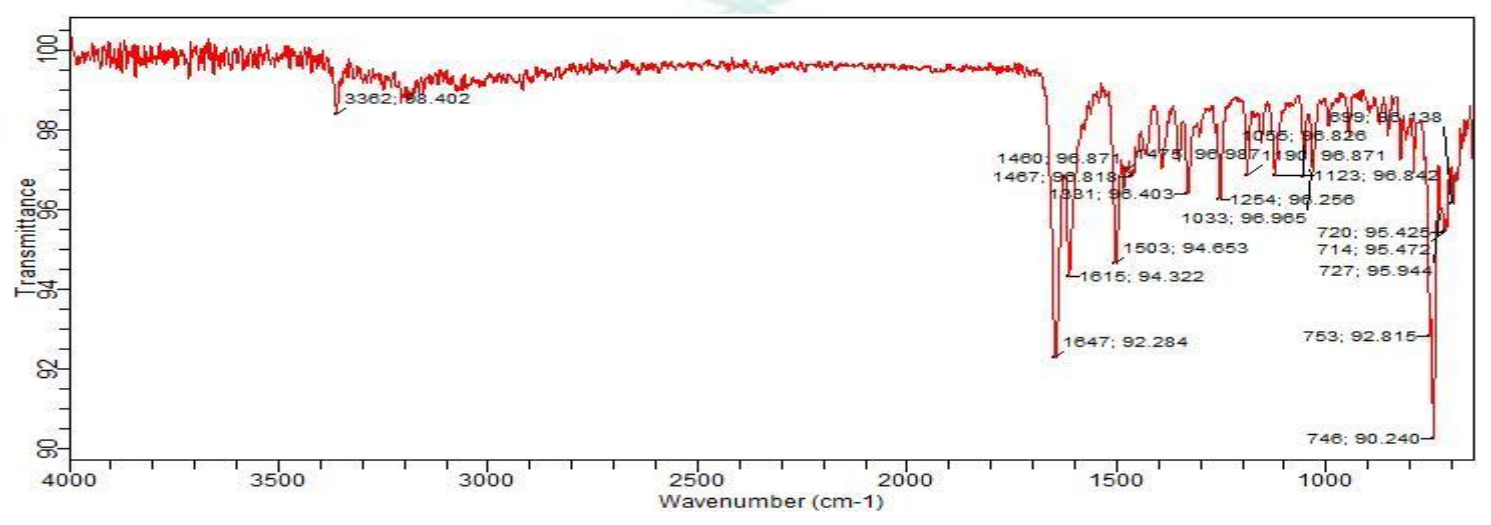

Figure 5: FTIR Spectrum of Microcrystalline cellulose

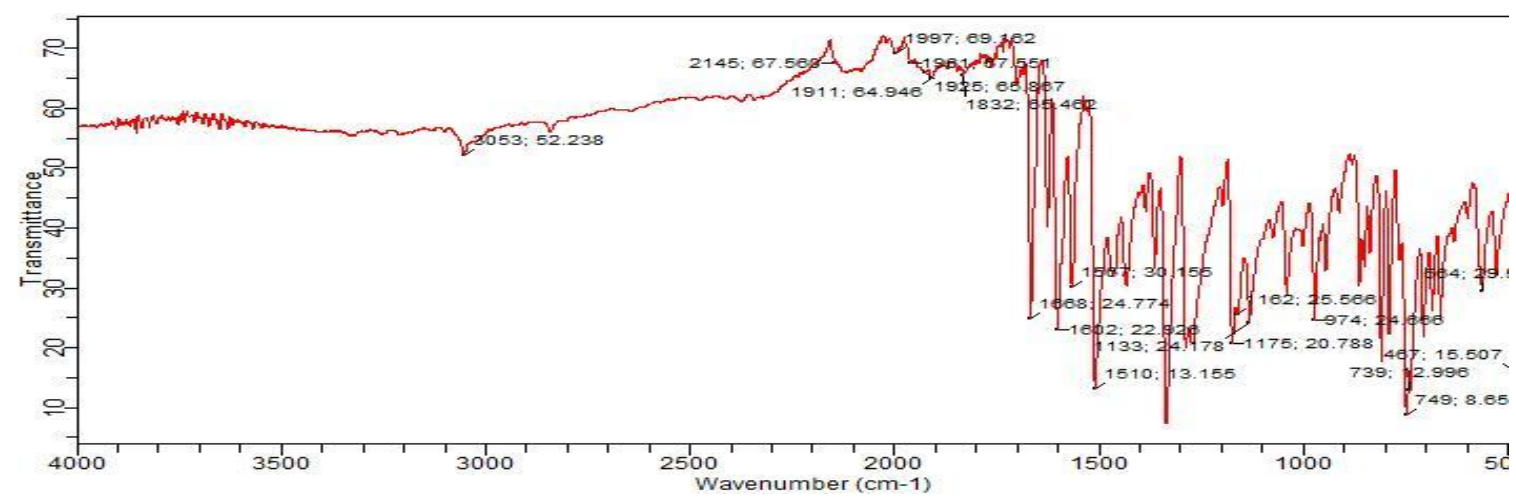

Figure 6: FTIR Spectrum of Mixtrue of compounds 
Table 2: Interpretation of Drug, Polymers with mixture of compounds

\begin{tabular}{|c|c|c|c|c|}
\hline SI.No & Name of the sample & Observed Peak & Bond & Functional Group \\
\hline \multirow[t]{4}{*}{1} & \multirow{4}{*}{$\begin{array}{l}\text { Sample } 1 \text { (Pure drug } \\
\text { (Cefotaxime) }\end{array}$} & 666 & $(\mathrm{~s})=\mathrm{C}-\mathrm{H}$ bend & Alkenes \\
\hline & & 1017 & (s)C-O stretch & Alcohol, carboxylic acid \\
\hline & & 1244 & (s) C-N stretch & Aromatic amines \\
\hline & & 3204 & $(\mathrm{~s}, \mathrm{~b}) \mathrm{O}-\mathrm{H}$ stretch & H-bonded alcohols, phenols \\
\hline \multirow[t]{4}{*}{2} & \multirow{4}{*}{$\begin{array}{l}\text { Sample 2 } \\
\text { (HPMCK15M ) }\end{array}$} & 753 & (m) C-Cl stretch & alkyl halides \\
\hline & & 1669 & (s) $\mathrm{C}=\mathrm{O}$ stretch & Carbonyl \\
\hline & & 2932 & (m) O-H stretch & Carboxylic acids \\
\hline & & 3194 & $(\mathrm{~m})=\mathrm{C}-\mathrm{H}$ stretch & Alkenes \\
\hline \multirow[t]{4}{*}{3} & \multirow{4}{*}{ Sample 3 (Guargum) } & 749 & (m) C-Cl stretch & Alkyl halides \\
\hline & & 1322 & $\begin{array}{l}\text { (m) N-O symmetric } \\
\text { stretch }\end{array}$ & Nitro compounds \\
\hline & & 1602 & (m) N-H bend & $1^{0}$ amines \\
\hline & & 3055 & (m) O-H stretch & Carboxylic acid \\
\hline \multirow[t]{3}{*}{4} & \multirow[t]{3}{*}{ Sample 4 (Chitosan) } & 745 & $(\mathrm{~s})=\mathrm{C}-\mathrm{H}$ bend & Alkenes \\
\hline & & 1056 & (s)C-O stretch & $\begin{array}{l}\text { Alcohol, carboxylicacid, } \\
\text { esters, ethers }\end{array}$ \\
\hline & & 1331 & (s)C-N stretch & Aromatic amines \\
\hline \multirow[t]{3}{*}{5} & \multirow{3}{*}{$\begin{array}{l}\text { Sample } 5 \\
\text { (Microcrystalline } \\
\text { cellulose) }\end{array}$} & 754 & (m) C-Cl stretch & alkyl halides \\
\hline & & 1140 & (m) C-N stretch & Aliphatic amines \\
\hline & & 2996 & (m) C-H stretch & Alkanes \\
\hline \multirow[t]{5}{*}{6} & \multirow{5}{*}{$\begin{array}{l}\text { Sample } 5 \\
\text { (Microcrystalline } \\
\text { cellulose) }\end{array}$} & 564 & (m) C-Br stretch & Alkyl hadlides \\
\hline & & 749 & $(\mathrm{~s})=\mathrm{C}-\mathrm{H}$ bend & Alkenes \\
\hline & & 1133 & (m) C-N stretch & Aliphatic amines \\
\hline & & 2145 & (w) -C \# C-stretch & Alkynes \\
\hline & & 3053 & $(\mathrm{~m})=\mathrm{C}-\mathrm{H}$ stretch & Alkenes \\
\hline
\end{tabular}

Pre-compression parameters:

Angle of repose: The results obtained for angle of repose for all the formulations. The values were found to be in the range of $21^{\circ} .32^{\prime}$ to $30^{\circ} .39^{\prime}$. Results as shown in table 3 . All the formulation showed the angle of repose below $30^{\circ}$, which indicates good flow.

Bulk density \& Tapped density: The loose bulk density and tapped bulk density for all the formulations varied from $0.38 \mathrm{gm} / \mathrm{cm}^{3}$ to $0.43 \mathrm{gm} / \mathrm{cm}^{3}$ and $0.41 \mathrm{gm} / \mathrm{cm}^{3}$ to $0.50 \mathrm{gm} / \mathrm{cm}^{3}$ respectively. The values obtained lies within the acceptable range and no large difference found between loose bulk density and tapped density. These results help in calculating the \% compressibility of the powder as shown in table 3 .
Percentage compressibility (carr's consolidation index): The percentage compressibility of powder mix was determined by the equation given for carr's consolidation index. The percentage compressibility lies within the range of 7.41 to 14.15 which indicates that the flow of the tablet mixture of various formulations is good to excellent. Results as shown in table 3.

Hausner's ratio: The Hausner's ratio of powder mix was determined by the data of loose bulk density and tapped bulk density. The Hausner's ratio for all the formulations lies within the range of 1.05 to 1.20 , which indicates flow of powder is excellent.

Table 3: Evaluation of pre-compression parameters of Cefotaxime with different formulations

\begin{tabular}{|c|c|c|c|c|c|}
\hline $\begin{array}{l}\text { Formulation } \\
\text { Code }\end{array}$ & $\begin{array}{l}\text { Bulk } \\
\text { density(g/cc) } \\
\text { MEAN } \pm \text { SD }\end{array}$ & $\begin{array}{l}\text { Tapped } \\
\text { density }(g / c c) \\
\text { MEAN } \pm \text { SD }\end{array}$ & $\begin{array}{l}\text { Hausner's } \\
\text { ratio } \\
\text { MEAN } \pm \text { SD }\end{array}$ & $\begin{array}{l}\text { Compressibility } \\
\text { index }(\%) \\
\text { MEAN } \pm \text { SD }\end{array}$ & $\begin{array}{l}\text { Angle of } \\
\operatorname{repose}(\theta) \\
\text { MEAN } \pm \text { SD }\end{array}$ \\
\hline $\mathrm{F} 1$ & $0.40 \pm 0.03$ & $0.44 \pm 0.05$ & $1.06 \pm 0.02$ & $7.50 \pm 0.04$ & $27.55 \pm 0.04$ \\
\hline $\mathrm{F} 2$ & $0.42 \pm 0.05$ & $0.50 \pm 0.04$ & $1.29 \pm 0.03$ & $14.15 \pm 0.02$ & $30.39 \pm 0.03$ \\
\hline F3 & $0.43 \pm 0.03$ & $0.41 \pm 0.02$ & $1.16 \pm 0.05$ & $10.52 \pm 0.05$ & $23.31 \pm 0.02$ \\
\hline $\mathrm{F} 4$ & $0.41 \pm 0.04$ & $0.42 \pm 0.05$ & $1.14 \pm 0.06$ & $10.25 \pm 0.04$ & $24.81 \pm 0.05$ \\
\hline F5 & $0.41 \pm 0.02$ & $0.43 \pm 0.02$ & $1.05 \pm 0.02$ & $7.69 \pm 0.02$ & $28.65 \pm 0.02$ \\
\hline F6 & $0.42 \pm 0.06$ & $0.45 \pm 0.07$ & $1.16 \pm 0.04$ & $10.25 \pm 0.05$ & $27.74 \pm 0.03$ \\
\hline F7 & $0.40 \pm 0.05$ & $0.46 \pm 0.05$ & $1.09 \pm 0.02$ & $7.50 \pm 0.07$ & $28.39 \pm 0.02$ \\
\hline F8 & $0.38 \pm 0.03$ & $0.43 \pm 0.02$ & $1.07 \pm 0.03$ & $7.41 \pm 0.02$ & $23.81 \pm 0.06$ \\
\hline F9 & $0.41 \pm 0.04$ & $0.45 \pm 0.06$ & $1.10 \pm 0.06$ & $7.69 \pm 0.06$ & $24.81 \pm 0.05$ \\
\hline
\end{tabular}

Each value represents the mean \pm standard deviation $(n=3)$ 


\section{Post compression parameters:}

Shape and thickness: Macroscopic examination of the tablets from each formulation showed circular shape with no cracks. Results as shown in table 4. The thickness of tablet randomly was measured using vernier callipers.

Weight variation test: All the formulations passed weight variation test as the percent weight variation was within the pharmacopoeia limits of $\pm 5 \%$. It was found to be from 399.41 to $499.09 \mathrm{mg}$. Results as shown in table 4. None of the formulations were exceeding the limit $\pm 5 \%$ specified by IP. Thus all the formulations were found to comply with the IP standard.

Hardness of the tablets: The tablet hardness of all the formulations was checked using Monsanto hardness tester, by the method described in methodology section. The average hardness of all the batches is in the range of 4.5 to $3.5 \mathrm{~kg} / \mathrm{m}^{2}$. The lower standard deviation values indicated that the hardness of all the formulations were almost uniform in specific method and possess good mechanical strength with sufficient hardness. Results as shown in table 4 . The hardness of all formulations was found to be in acceptable range.

Friability of the tablets: The friability test is designed to evaluate the ability of the tablet to withstand abrasion in packaging, handling and shipping. A number of tables were weighed and placed in tumbling apparatus where they were exposed to rolling and 50 resolutions resulting from freefalls within the roche's apparatus. Results as shown in table 4 . The percentage friability for all the formulations lies in the range of $0.12 \%$ to $0.45 \%$, which was found to be in limit (i.e. $<1 \%$ ).

Estimation of drug content: All the formulations were evaluated for the drug content estimation in $0.1 \mathrm{NHCl}$ sample of tablets using the procedure described in methodology section. Results as shown in table 4 . The drug content values for all the formulations are in the range of 98 to $99 \%$.

Table 4: Evaluation of Post Compression Parameters of Different Formulations cefotaxime tablet floating drug delivery by using raft forming approach

\begin{tabular}{|c|c|c|c|c|c|}
\hline $\begin{array}{c}\text { Formulation } \\
\text { code }\end{array}$ & $\begin{array}{c}\text { Hardness } \\
\left(\mathbf{k g} / \mathrm{cm}^{2}\right) \\
\text { MEAN } \pm \text { SD } \\
(\mathbf{n}=3)\end{array}$ & $\begin{array}{c}\text { Thickness } \\
(\mathbf{m m}) \\
\text { MEAN } \pm \text { SD } \\
(\mathbf{n}=\mathbf{3})\end{array}$ & $\begin{array}{c}\text { Weight } \\
\text { variation(mg) } \\
\text { MEAN } \pm \text { SD } \\
(\mathbf{n}=\mathbf{2 0})\end{array}$ & $\begin{array}{c}\text { Friability } \\
(\%) \\
\text { MEAN } \pm \text { SD } \\
(\mathbf{n}=3)\end{array}$ & $\begin{array}{c}\text { Drug content } \\
(\%) \\
(n=2)\end{array}$ \\
\hline F1 & $3.9 \pm 0.3$ & $6.0 \pm 0.4$ & $399.41 \pm 0.32$ & $0.20 \pm 0.17$ & 98.23 \\
\hline $\mathrm{F} 2$ & $4.3 \pm 0.1$ & $6.1 \pm 0.1$ & $460.09 \pm 0.57$ & $0.12 \pm 0.15$ & 99.52 \\
\hline F3 & $4.1 \pm 0.3$ & $5.8 \pm 0.2$ & $450.57 \pm 0.26$ & $0.35 \pm 0.14$ & 98.48 \\
\hline $\mathrm{F} 4$ & $4.4 \pm 0.4$ & $6.4 \pm 0.3$ & $443.46 \pm 0.39$ & $0.29 \pm 0.12$ & 99.01 \\
\hline F5 & $3.9 \pm 0.2$ & $6.7 \pm 0.2$ & $467.33 \pm 0.23$ & $0.30 \pm 0.16$ & 98.26 \\
\hline F6 & $4.0 \pm 0.3$ & $6.5 \pm 0.1$ & $478.25 \pm 0.62$ & $0.35 \pm 0.14$ & 99.11 \\
\hline F7 & $4.2 \pm 0.2$ & $6.8 \pm 0.3$ & $434.72 \pm 0.47$ & $0.42 \pm 0.13$ & 99.10 \\
\hline F8 & $4.4 \pm 0.2$ & $6.9 \pm 0.3$ & $499.01 \pm 0.28$ & $0.45 \pm 0.18$ & 98.65 \\
\hline F9 & $3.9 \pm 0.3$ & $6.3 \pm 0.2$ & $423.03 \pm 0.43$ & $0.43 \pm 0.16$ & 98.47 \\
\hline
\end{tabular}

Each value represents the mean \pm standard deviation

In-vitro drug release studies: The In-vitro dissolution study of Cefotaxime tablet floating drug delivery by using raft forming approach, $0.1 \mathrm{~N} \mathrm{HCl}$ as dissolution medium. The In-vitro drug release study of Cefotaxime tablets from each batch (F1 to F9) was carried out by using $0.1 \mathrm{~N} \mathrm{HCl}$ for 45 Mints. The samples were withdrawn at specified time intervals and analyzed by UV-visible spectrophotometer. Percentage drug release was calculated on the basis of mean amount gastro retentive of Cefotaxime present in respective formulation. The cumulative percentage of drug release of floating drug delivery of Cefotaxime on y-axis was plotted against time on $\mathrm{x}$-axis to obtain drug release profiles.

Drug Release Kinetics: The release constant was calculated from the slope of the appropriate plots, and the regression coefficient $\left(\mathrm{r}^{2}\right)$ was determined The drug release data obtained were extrapolated by Zero order, First order, Higuchi model and Korsmeyer-Peppas plot for Best Formulation F7. The release kinetics shows that the release of drug followed zero order release in all the formulations.

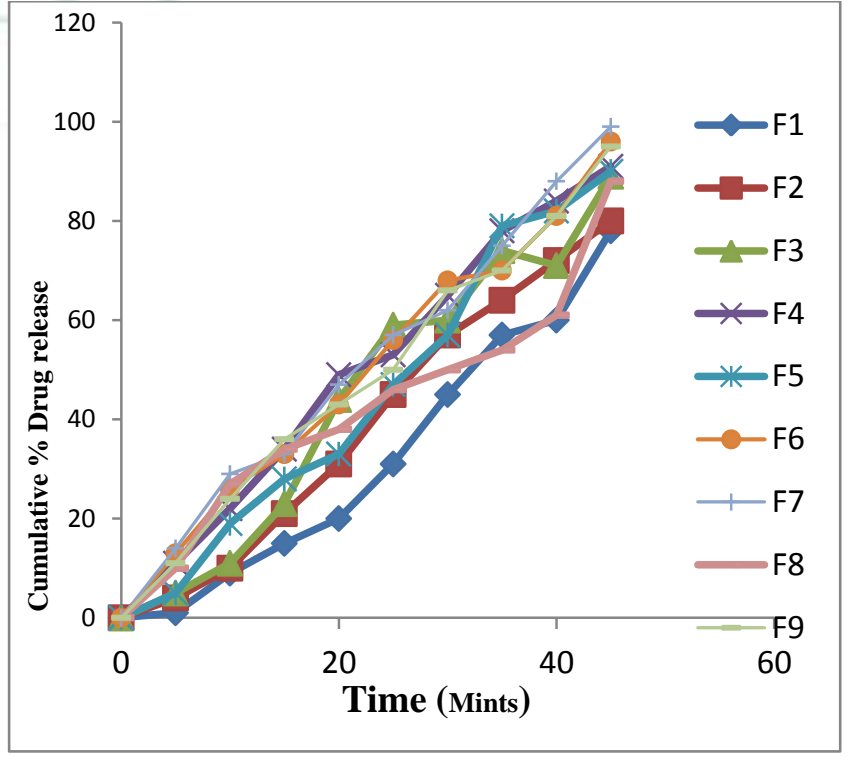

Figure 7: In Vitro dissolution Studies cefotaxime tablet floating drug delivery by using raft forming approach 
Table 5: Release kinetics of cefotaxime tablet floating drug delivery by using raft forming approach F1 to F5

\begin{tabular}{|l|l|l|l|l|l|l|l|l|l|l|l|l|}
\hline Model & Equation & \multicolumn{2}{l}{$\mathrm{F} 1$} & $\mathrm{~F} 2$ & $\mathrm{~F} 3$ & $\mathrm{~F} 4$ & \multicolumn{2}{l|}{$\mathrm{F} 5$} \\
\cline { 2 - 13 } & & $\mathrm{R}^{2}$ & $\mathrm{~m}$ & $\mathrm{R}^{2}$ & $\mathrm{~m}$ & $\mathrm{R}^{2}$ & $\mathrm{M}$ & $\mathrm{R}^{2}$ & $\mathrm{~m}$ & $\mathrm{R}^{2}$ & $\mathrm{M}$ \\
\hline Zero order & Mo-Mt=kt & 0.655 & 69.4 & 0.939 & 1123 & 0.007 & 15.93 & 0.202 & 72.88 & 0.928 & 1414 \\
\hline First order & $\mathrm{InM}=\mathrm{InMo}$ & 0.494 & 0.061 & 0.540 & 0.067 & 0.257 & 0.038 & 0.352 & 0.044 & 0.438 & 0.062 \\
\hline $\begin{array}{l}\text { Higuchi's } \\
\text { Matrix }\end{array}$ & $\begin{array}{l}M_{0}-M_{\mathrm{t}} \\
k t 1 / 2\end{array}$ & 0.516 & 4508 & 0.767 & 7420 & 0.023 & 212.0 & 0.189 & 515.5 & 0.803 & 9618 \\
\hline $\begin{array}{l}\text { Korsmeyer- } \\
\text { Peppar }\end{array}$ & $\begin{array}{l}\log \left(M_{0}-M_{\mathrm{t}}\right)= \\
\log k+n \log t\end{array}$ & 0.835 & 2.354 & 0.884 & 2.545 & 0.572 & 1.709 & 0.663 & 1.813 & 0.806 & 2.517 \\
\hline
\end{tabular}

Table 6: Release kinetics of cefotaxime tablet floating drug delivery by using raft forming approach F6 to F9

\begin{tabular}{|l|l|l|l|l|l|l|l|l|l|}
\hline \multirow{2}{*}{ Model } & Equation & \multicolumn{2}{l|}{$\mathrm{F} 6$} & \multicolumn{2}{l|}{$\mathrm{F} 7$} & \multicolumn{3}{l|}{ F8 } \\
\cline { 3 - 10 } & & $\mathrm{R}^{2}$ & $\mathrm{~m}$ & $\mathrm{R}^{2}$ & $\mathrm{~m}$ & $\mathrm{R}^{2}$ & $\mathrm{M}$ & $\mathrm{R}^{2}$ & $\mathrm{M}$ \\
\hline Zero order & Mo-Mt=kt & 0.917 & 15.49 & 0.949 & 154.4 & 0.937 & 1593 & 0.945 & 139.7 \\
\hline First order & $\mathrm{InM}=\mathrm{InMo}$ & 0.481 & 0.052 & 0.465 & 0.051 & 0.399 & 0.061 & 0.478 & 0.051 \\
\hline $\begin{array}{l}\text { Higuchi's } \\
\text { Matrix }\end{array}$ & $M_{0}-M_{\mathrm{t}}=k t 1 / 2$ & 0.798 & 1057 & 0.848 & 1067 & 0.899 & 1149 & 0.836 & 960.9 \\
\hline $\begin{array}{l}\text { Korsmeyer- } \\
\text { Peppar }\end{array}$ & $\begin{array}{l}\log \left(M_{0^{-}}\right. \\
\left.M_{\mathrm{t}}\right)=\log k+n \log t\end{array}$ & 0.835 & 2.032 & 0.827 & 2.033 & 0.785 & 2.560 & 0.838 & 2.018 \\
\hline
\end{tabular}

In-vitro Buoyancy Studies: The all formulation were showed good floating lag time and total floating time. The FLT and TFT of the tablets mainly depend on the type of polymer and their concentrate, as shown in figure $8 \&$ table 7 .
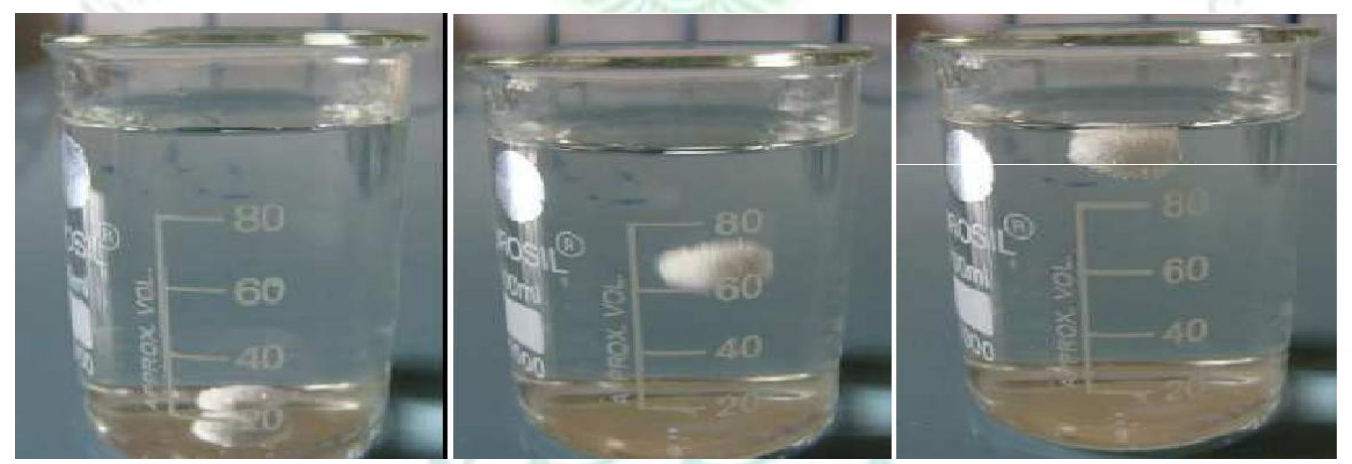

Figure 8: Buoyancy floating of formulated floating tablets

Table 7: Floating lag time of the gastro retentive tablets (F1-F9)

\begin{tabular}{|l|c|c|}
\hline Formulation Code & Floating lag time (sec) & Total floating time (hour) \\
\hline F1 & 23 & 12 \\
\hline F2 & 36 & 12 \\
\hline F3 & 28 & 12 \\
\hline F4 & 42 & 12 \\
\hline F5 & 10 & 10 \\
\hline F6 & 16 & 10 \\
\hline F7 & 18 & 12 \\
\hline F8 & 26 & 12 \\
\hline F9 & 31 & 12 \\
\hline
\end{tabular}

Stability Study: Optimized formulation F7 was subjected to stability studies for 1 to 3 months and the tablets were tested for drug content and dissolution. The results obtained were as in the following figure 9. 


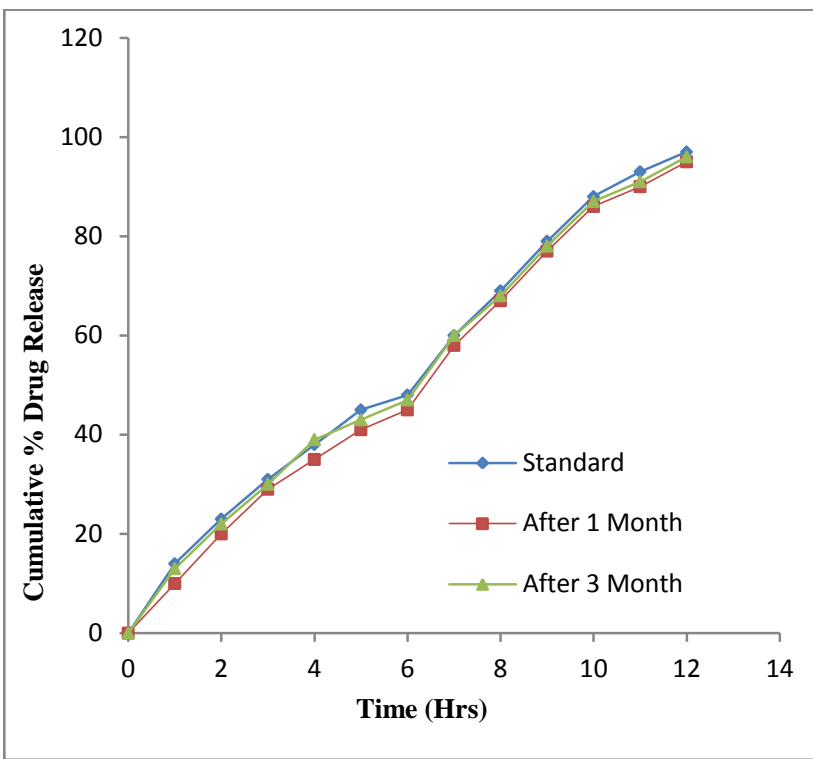

Figure 9: Stability studies of Optimized In-vitro Cumulative \% Drug release of $\mathrm{F} 7$

Comparison of dissolution profile of optimized formulation (F7) with marketed product: The prepared all F7 formulations, the tablets made with combination of chitosan F7 showed better results of dissolution. It has showed $98.6 \%$ dissolution in 12 hours. This formulation was compared with marketed formulation shown in figure 10 .

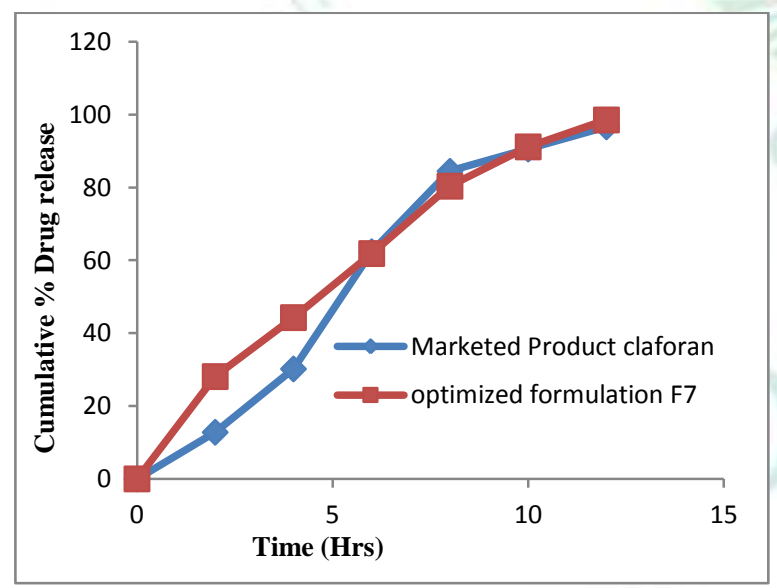

Figure 10: Comparison of dissolution profile of F7 and Marketed product

\section{SUMMARY}

The cefotaxime drug is used for the treatment for antibacterial disease by the mechanism bactericidal action of cefotaxime inhibits cell wall synthesis. It binds the penicillin binding proteins. The main of this project work to improve the patient complains quick relies of the drug, improve bioavailability and improve therapeutic effectiveness. For this purpose formulate the floating drug delivery of cefotaxime tablet by using raft forming approach. Drug polymer compatibility studies by observing physical observation, FTIR, analysis revealed that there was no significant physical \& chemical interaction between the drug and polymers. Hence, the selected raw materials were more suitable for the formulation of cefotaxime tablet linearity of the curve was observed in the calibration curve, which was found to be wavelength $752 \mathrm{~nm}$. Nine formulations were prepared by using the different ratios of the polymers such as the HPMC K15M, Guargum, Chitosan, Sodium bicarbonate was in cooperated as an effervescent substance to study the buoyancy of the dosage form due to liberation of $\mathrm{CO}_{2}$, Sodiumalginate is used as viscous gel forming agent, Microcrystalcellulose used as binder, Talc is used as diluents, Magnesium stearate lubricant. The formulated cefotaxime tablet to be evaluated the following parameters as follow Weight variation, Hardness, Thickness, Friability, Drug content uniformity, Floating lag time, the in vitro cumulative amount of drug released was shown the F7 is $98 \%$ within 12 Hours the comparative studies with marketed formulations F7 show the better results.

CONCLUSION: From the experimental results, it can be concluded that the sodium bicarbonate and sodium alginate has shown a predominant effect on the buoyancy lag time, while HPMC K15M and Guar gum have the predominant effect on drug release. Floating drug delivery of cefotaxime tablet has controlled release. In vitro release rate studies showed that the maximum drug release was observed F7 formulation upto 12 hours. From the study it is evident that promising controlled release tablets of cefotaxime can be developed. Further detailed investigations are required to establish efficacy of these formulations. 


\section{REFERENCES:}

1. Deshbhratar RM, Studies on Formulation and In-vitro Evaluation of Gastro Retentive Drug Delivery System of Carbamazepine; International Journal of Chem Tech Research 2010; 2(1):108-113.

2. Dey S, UV Spectrophotometric Determination of Cefixime in Bulk and its Dosage Form, Journal of Pharmacy Research, 2012; 5(12):5419-5422.

3. Janakidevi S, Design and Optimization of Cefixime Trihydrate Sustained Matrix Tablets Using Different Polymers, International Research Journal of Pharmacy, 2014; 7(5):619 625 .

4. Streubel A, Siepmann J, Bodmeier R, Drug Delivery to the upper small intestine window using Gastro retentive technologies. Curr Opin Pharmacol, 2006; 6:501-508.

5. Rubinstein, MH, Physiological Pharmaceutical: Biological barriers to the drug absorption. Chichester, U.k: Ellis Horwood. 1989, P.47-70.

6. Whitehead L, Fell JT and Collett JH. Development of a gastroretentive dosage form. Eur J Pharm Sci, 1996; 4:182188.

7. Birajdar shiv Prasad M, BhusnureOG, S. Mulaje S, formulation and evaluation of fast disintegrating losartan tablets by formal experimental design, international journal of research and development in pharmacy and life sciences, 2014; 3(1):1136-1150.

8. Devareddy S, Krishnarajan D, Manivannan R, Senthilkamar N. Formulation and Evaluation of Losartan Potassium and Hydrochloriazide Conventional Release Tablets, International Research Journal of Pharmacy, 2012; 3(6):159-164.

9. Gehan balata, Formulation and Evaluation of Gastro-retentive Floating Tablet of Nizatidine. International Journal of Pharmacy and Pharmaceutical Sciences, 2014; 6(5):423-429.

10. Haranadh CH, Lokeshreddy M, Vaseedhar B, Sabareesh M, Umasankar K. Formulation and evaluation of hydrogel based oral controlled drug delivery system for losartan potassium. International Journal of Research in Pharmaceutical and Nano sciences, 2014; 3(3):190-199.

11. Patel J, Patel A, Sheth Z, Development of Floating Tablet Containing Roxatidine Acetate by Statistical Optimization Technique, International Journal of Pharmaceutical Science, 2014; 3(5):201-210.

12. Jagadale $\mathrm{S} \mathrm{K}$, Patil $\mathrm{P} \mathrm{S}$ and Navele $\mathrm{R}$, Formulation and Evaluation of Orally Disintergrating Tablet of Losartan Potassium by Direct Compression Method. Research journal of pharmaceutical biological and chemical sciences, 2013, 4(4):127-135.

13. Janimini M, Shrivastava B, Tanwar V.S, Formulation and Evaluation of Effervescent Floating Matrix Tablet of Losartan
Potassium, International Journal of Pharmaceutical Innovations, 2011; 1(5):82-87.

14. Katyayini S, Sellappanvelmurugan, Formulation and Evaluation of Effervescent Floating Tablets of Losartan Potassium, International Journal of Pharmacy and Pharmaceutical sciences, 2013; 5(3):559-565.

15. Latha K, Uhumwangho MU, Sunil SA, Srikanth MV, Ramana murthy KV, Formulation and Evaluation of Oral Time Release Tablets of Losartan Potassium Using Natural Gum and its Solid Characterization, 2012; 4(5):89-95.

16. Manjula B, B. Mohammed Ishaq, C. Hari Kumar, Usha Rani G. Formulation and Evaluation of Gastro retentive Floating Drug Delivery System of Ketoprofen. Scholars Research Library, Der Pharmacia Lettre, 2010; 2(3):197-208.

17. Janimini M, Tanwar YS, Srivastava B, Formulation and Evaluation of Gastro Retentive Drug Delivery System of Losartan Potassium, International Current Pharmaceutical Journal, 2012; 2(1):11-17.

18. Chandira M, Bhowmik D, Chiranjib,.Jayakar B, Formulation Evaluation of Gastro retentive Drug Delivery System of Gastroprokinetic drug Itopride hydrochloride, International Journal of Pharmacy and Pharmaceutical Sciences, 2010; 2(1):53-65

19. Janimini M, Shrivastava B, Tanwar V.S, Formulation and Evaluation of Effervescent Floating Matrix Tablet of Losartan Potassium, International Journal of Pharmaceutical Innovations, 2011; 1(5): 82-87.

20. Katyayini S, Sellappanvel Murugan, Formulation and Evaluation of Effervescent Floating Tablets of Losartan Potassium, International Journal of Pharmacy and Pharmaceutical Sciences, 2013; 5(3):559-565.

21. Keshari A, Tripathi DPK, Srivastava A, Vishwas R, Formulation and evaluation of effervecent floating tablets of antidiabetic drug. Journal of Drug Delivery and Therapeutics. 2015; 5(6):43-55

22. Janimini M, Tanwar YS, Birendrasrivastava, Formulation and Evaluation of Gastro Retentive Drug Delivery System of Losartan potassium, International Current Pharmaceutical Journal, 2012; 2(1):11-17.

23. Manjula B, Formulation and Evaluation Gastro Retentive Floating Drug Delivery System of Ketoprofen, Scholars research library, 2010; 2(3):197-208.

24. Margret chandira R, Debit Bhowmik, Chiranji B, and B. Jayakar, Formulation \& Evaluation of Gastro Retentive Drug Delivery System of Gastroprokinetic drug Itopride hydrochloride, International Journal of Pharmacy and Pharmaceutical Sciences, 2010; 2(1):53-65. 